\title{
Accuracy of Air-Sea Heat and Momentum Fluxes in the Sea South of Japan
}

\author{
By Kimio Hanawa \\ Department of Geophysics, Faculty of Science, Tohoku University, Sendai 980, Japan \\ (Manuscript received 20 May 1987, in revised form 27 July 1987)
}

\begin{abstract}
Based on the statistical consideration for air-sea sensible and latent heat and momentum fluxes estimated from the data obtained at OWS $-\mathrm{T}\left(29^{\circ} \mathrm{N}, 135^{\circ} \mathrm{E}\right)$ from June 1950 to November 1953, the relationship between the standard error of monthly mean fluxes and the number of the data used in estimation was examined. The standard errors varying seasonally for the number of the data were presented, which were given by the statistical theory, i.e., the standard deviation of the population divided by the square root of the number of the sampled data. These results were also confirmed by the computer simulation for randomly sampled and small-in-number data, and they holded even though the distribtuion of the population deviates from the normal one. From the actual number of the marine metcorological data compiled by the Japan Meteorological Agency from 1961 to 1985, it could be expected that in the sea south of Japan, momentum fluxes can be estimated with accuracies of 0.15 and $0.1 \mathrm{dyn} \cdot \mathrm{cm}^{-2}$ in winter and summer, respectively, the sensible heat fluxes 5 and $1 \mathrm{~W} \cdot \mathrm{m}^{-2}$ and the latent heat fluxes 15 and $5 \mathrm{~W} \cdot \mathrm{m}^{-2}$.
\end{abstract}

\section{Introduction}

How many marine meteorological data are needed to estimate long-term (monthly or so) mean air-sea heat and momentum fluxes with accuracy required for some purpose? This question is difficult to exactly answer, and consideration for this has not been made so far necessarily by authors who estimated the global air-sea heat and momentum fluxes. However, it is unavoidable to clarify reliability of estimated fluxes in order to successfully accomplish research programs such as WOCE or TOGA closely relating to long-term oceanic variability.

Recently, an improvement of the remote sensing technology enables us to estimate several marine meteorological elements such as SST, atmospheric water vapor and the wind field simultaneously for wide area (e.g., Liu, 1987). Nevertheless, the data reported by ships-of-opportunity are the basic data sets for flux estimation by the aerodynamical bulk method presently.

The purpose of the present study is to answer the above mentioned question to some extent (C)1987, Meteorological Society of Japan for the sea south of Japan, based on the statistical consideration of fluxes estimated from the data obtained by Ocean Weather Station (OWS) and by using the actual number of the data reported by ships-of-opportunity.

In 1940's, observations of OWSs had been started, where the marine meteorological elements have been obtained every three hours with relatively high accuracies. Since the data in most parts of the ocean are sparse, detailed examinations for these data must be made from various viewpoints. These data as a matter of course can be used to solve the present problem. In this study, the data obtained at OWS-T $\left(29^{\circ} \mathrm{N}, 135^{\circ} \mathrm{E}\right.$, see Fig. 1) from June 1950 to November 1953 are used. Since the continuous observation was stopped in November 1953, the length of time series is rather short, i.e., 42 months. However, since there are no comparable data in the sea south of Japan, we need to examine them in detail. By using these data, Kurasawa et al. (1983) reported on the heat balance of the upper ocean and Hanawa and Toba (1987) examined the various estimation methods of long-term mean air-sea heat and momentum fluxes. See both papers on the data obtained at OWS-T. 


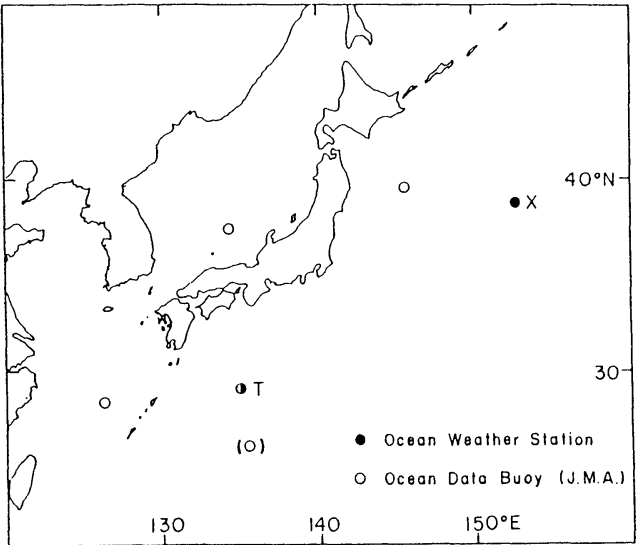

Fig. 1. Positions of old Ocean Weather Stations T and $\mathrm{X}$, and Ocean Data Buoys operated by the Japan Meteorological Agency. Ocean Data Buoy in parentheses is out of operation now.

The contents of this paper are as follows: in Section 2, characteristics of variations of fluxes are described. In Section 3, error of monthly mean fluxes using the randomly sampled and small-in-number data is considered, and in Section 4 the actual distribution of the data compiled in the Japan Meteorological Agency is presented. The expected accuracies of monthly mean fluxes in the sea south of Japan are discussed in Section 5. Section 6 gives discussion.

\section{Characteristics of variations of heat and momentum fluxes at OWS-T}

Air-sea heat and momentum fluxes were estimated by the aerodynamical bulk method: eastwest and north-south wind stresses, sensible and latent heat fluxes. The bulk transfer coefficients used here were those proposed by Kondo (1975). For estimation of monthly mean value of fluxes, the sampling method was adopted: this method is one in which the averaging of the estimated fluxes for a month is performed, after calculations of the heat and momentum fluxes are made by means of simultaneous observational data. See Hanawa and Toba (1987) for detailes of this method together with other estimation methods.

Figure 2 shows the seasonal variation of monthly mean flux of each component and that of standard deviation. Mean values of each calendar month for three or four years can be de-

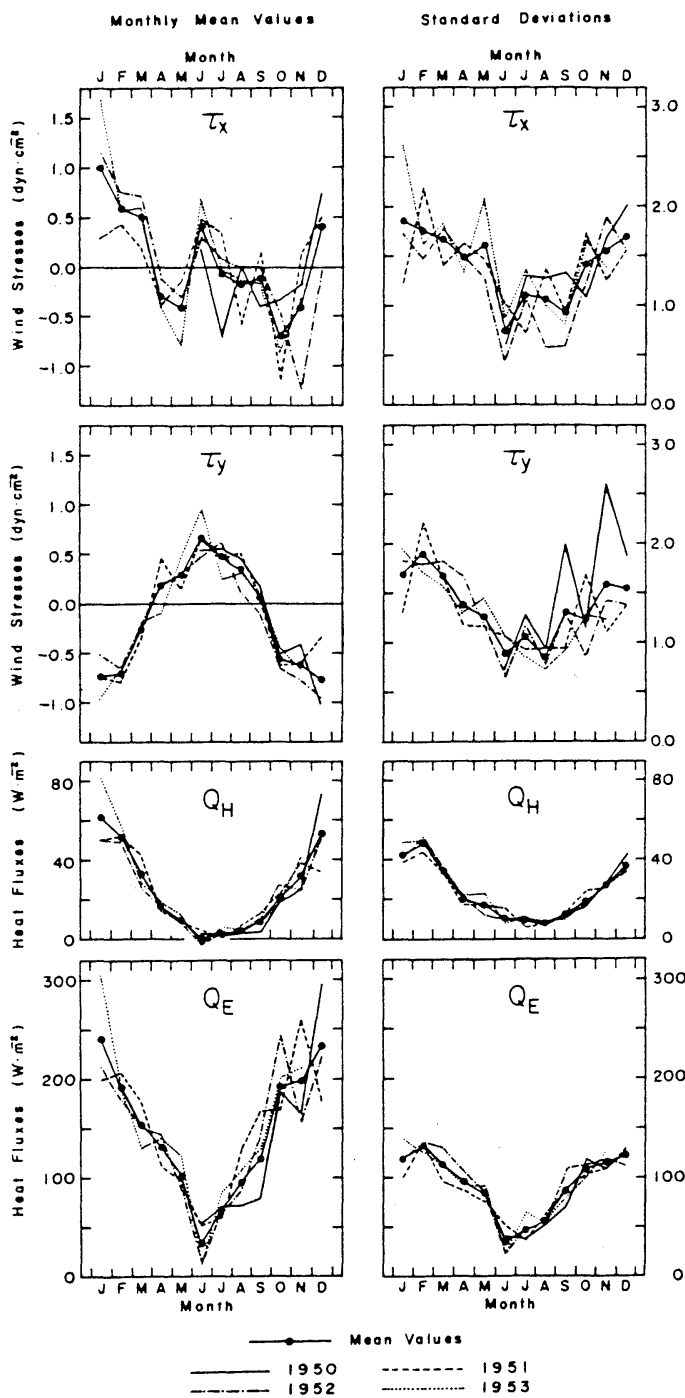

Fig. 2. Seasonal variations of monthly mean heat and momentum fluxes (left panels) and those of standard deviation (right): east-west wind stress $\left(\tau_{x}\right)$, northsouth wind stress $\left(\tau_{y}\right)$, sensible heat flux $\left(Q_{H}\right)$ and latent heat flux $\left(Q_{E}\right)$ from the top to bottom panels.

scribed as follows. In winter, a northwesterly wind prevails and the magnitude of wind stress reaches $1-1.3 \mathrm{dyn} \cdot \mathrm{cm}^{-2}$. In summer a southerly wind dominates and wind stress reduces to about $0.5 \mathrm{dyn} \cdot \mathrm{cm}^{-2}$. Their standard deviations are relatively high $\left(1.5-2.0 \mathrm{dyn} \cdot \mathrm{cm}^{-2}\right)$ in winter and low $\left(1 \mathrm{dyn} \cdot \mathrm{cm}^{-2}\right)$ in summer. Sensible heat fluxes take the maximum value of $60 \mathrm{~W} \cdot \mathrm{m}^{-2}$ in February, while they take values less than 5 $\mathrm{W} \cdot \mathrm{m}^{-2}$ in summer. Their standard deviations show clear seasonal variation similar to that of 

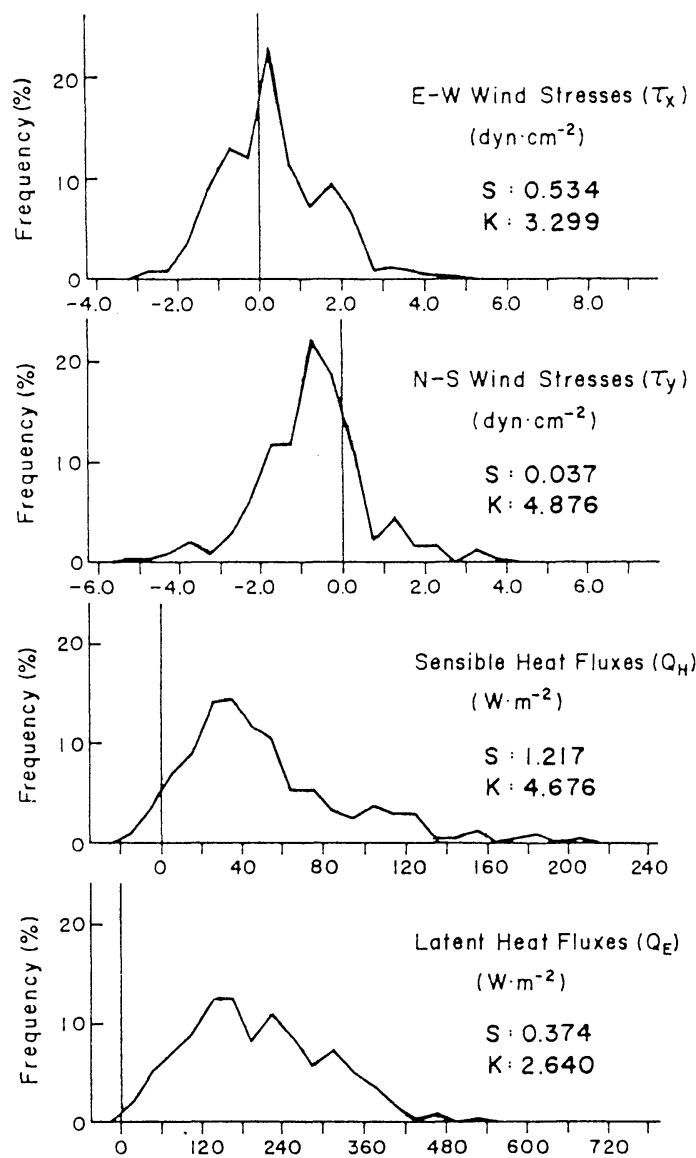

Fig. 3. Example of frequency distribution (\%) of original momentum and heat fluxes. Ranges of division of fluxes are $0.5 \mathrm{dyn} \cdot \mathrm{cm}^{-2}$ for wind stresses, $10 \mathrm{~W}$. $\mathrm{m}^{-2}$ for sensible heat flux and $30 \mathrm{~W} \cdot \mathrm{m}^{-2}$ for latent heat flux. These data are those in January 1951. Symbols $\mathrm{S}$ and $\mathrm{K}$ with numerical values in each panel denote the skewness and kurtosis. Mean values are $\tau_{x}=0.29$ and $\tau_{y}=-0.76 \mathrm{dyn} \cdot \mathrm{cm}^{-2}, Q_{H}=50.0$ and $Q_{E}^{\prime}=199.0 \mathrm{~W} \cdot \mathrm{m}^{-2}$.

fluxes themselves with the maximum value of $40 \mathrm{~W} \cdot \mathrm{m}^{-2}$ in winter and the minimum value of $5 \mathrm{~W} \cdot \mathrm{m}^{-2}$ in summer. Latent heat fluxes are also large in winter with the maximum value of 250 $\mathrm{W} \cdot \mathrm{m}^{-2}$ in February and small in summer with the minimum value of $30 \mathrm{~W} \cdot \mathrm{m}^{-2}$ in June. Their standard deviations also show large seasonal variation with relatively high value in winter $(100$ $\mathrm{W} \cdot \mathrm{m}^{-2}$ ) and low value in summer (about 50 $\mathrm{W} \cdot \mathrm{m}^{-2}$ ). Note that the standard deviations especially for sensible and latent heat fluxes show stable seasonal variation during the period. Therefore, we will use those mean values as the plausible standard deviations of the population in the later section.

Next, we examined the distribution of an individual flux obtained every three hours (the population). Figure 3 shows an example of the frequency distribution of heat and momentum fluxes in January 1951. It is seen that the distribution deviates from the normal (Gaussian) distribution. The skewness and kurtosis for these distributions were shown in each panel of the figure. When the population is the normal distribution, the skewness and kurtosis take values of zero and 3, respectively. The positive skewness, which relates to $3 \mathrm{rd}$ order moment of the population, means that the distribution of the population has a long tail towards the positive side from the mean value, and vice versa. The kurtosis larger than 3 , which relates to 4 th order moment, means that the distribution disperses from the mean value compared with the normal one.

Figure 4 shows the seasonal variations of kurtosis and skewness of each component. The skewnesses are positive in almost all months for sensible and latent heat fluxes and they have both positive and negative values for wind stresses. The kurtosises are in general larger than 3 for wind stress and they largely change without clear seasonal dependency for sensible and latent heat fluxes. These facts show that the population usually deviates from the normal distribution.

\section{Error estimation for randomly sampled and small-in-number data}

In general, the data reported by ships-of-opportunity can be regarded as randomly sampled ones. Moreover, they are usually insufficient in number compared with those of OWSs. Therefore, error estimation must be made for randomly sampled and small-in-number data, since in the present time and near future, we cannot expect the data obtained regularly in time and distributed equally in space in most parts of the ocean.

In statistics, it is known that the standard error of the mean value of randomly sampled data, i.e., expected difference from the real mean value of the population, depends on the size of sampled data (e.g., Hays, 1981). That is, the standard error $\varepsilon$ is given by the standard devia- 

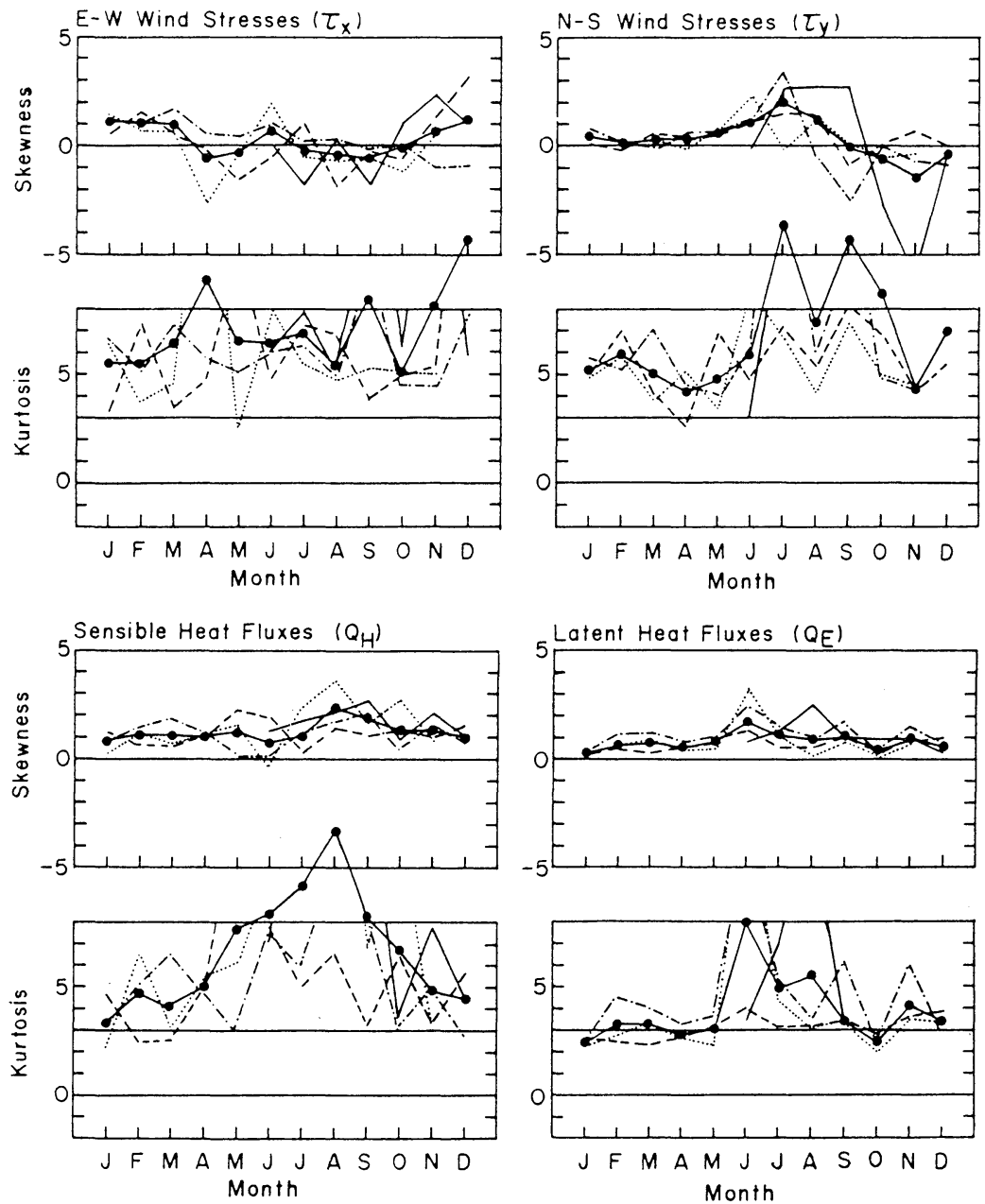

Fig. 4. Seasonal variations of skewness and kurtosis for each monthly mean flux. Kinds of lines are the same as Fig. 2, and lines except for mean values were not drawn when values are beyond the panel frame.

tion of population $\sigma_{0}$ divided by square root of the number of the data $N$ :

$$
\varepsilon=\sigma_{0} / N^{1 / 2} .
$$

Figure 5 shows the relationship between the standard error and the number of the data used in estimation, in which the solid and dashed lines show the relationship obtained by Eq. (1) for January and March 1951, respectively. The value for one data exactly corresponds to the standard deviation of the population. In order to confirm this theoretical relationship based on the actual data, we performed the computer simulation for the randomly sampled and small-in-number data. See Appendix on the procedures of the computer simulation. The agreement between the theoretical one and the result by the computer simulation is fairly good as shown in Fig. 5. It is also known that even though the distribution of the population deviates from the normal one, the mean values of randomly sampled data distribute like the normal distribution with skewness and kurtosis close to those of the normal one (see also Hays, 1981). Therefore, we can regard the standard error as the expected accuracy of fluxes estimated using randomly sampled and small-innumber data.

Since each standard deviation of heat and momentum transfers at OWS-T shows large seasonal variation as mentioned in the previous 

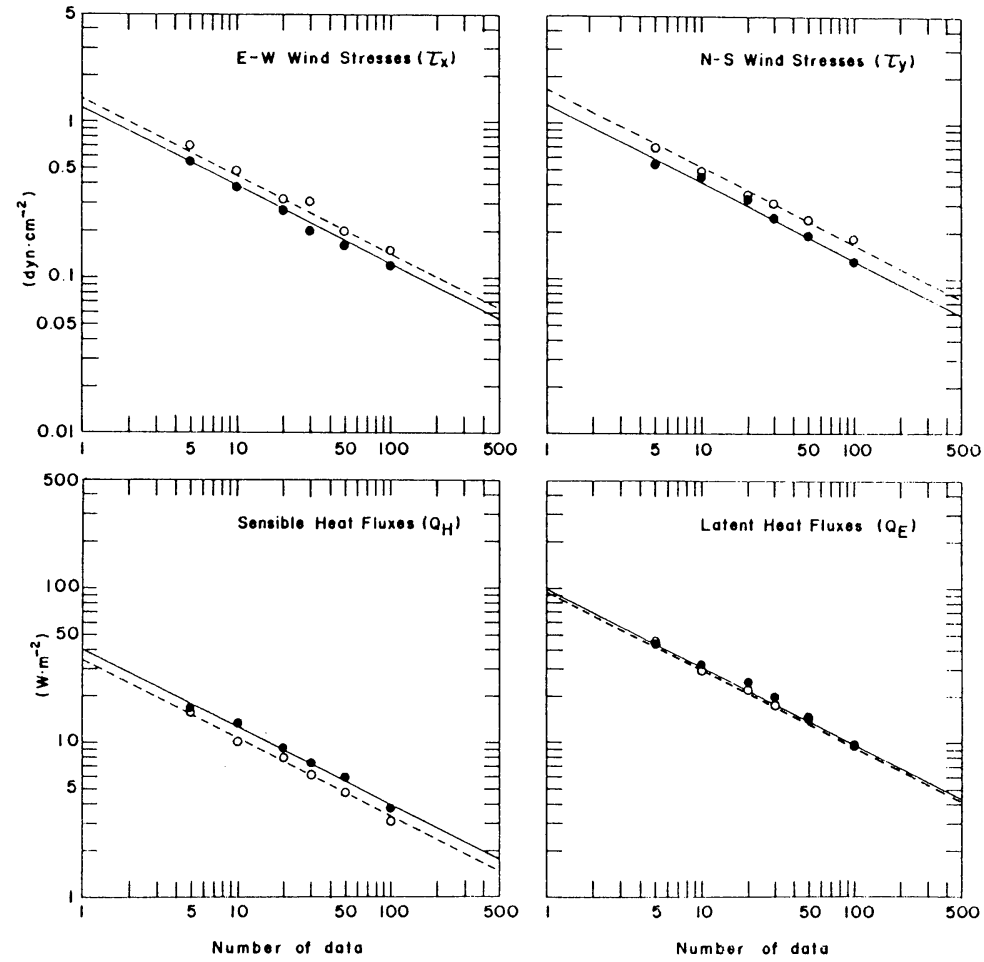

Fig. 5. Relationship between the standard error of each monthly flux and the number of the data used in estimation. The solid and dashed lines denote the relationship obtained theoretically by Eq. (1) for January and March 1951, respectively and black and open circles denote results of computer simulation for those months, respectively. See Appendix for the computer simulation.
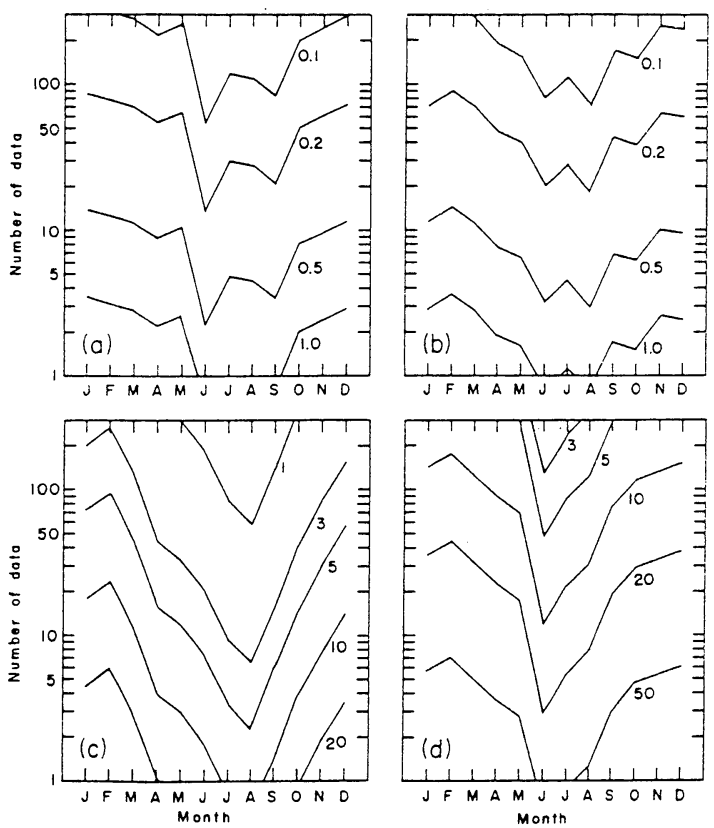

section, the expected accuracies also depend on season for the fixed number of the data. As a result, for the sea adjacent to OWS-T, we can obtain the relationship between the expected accuracy and the number of the data for each component as shown in Fig. 6.

\section{Actual number of compiled marine mete- orological data in the western North Pacific}

The actual number of the marine meteorological data was examined from the North Pacific Climate Table issued by the Japan Meteorological Agency and from the original tape compiled by the same agency. These compiled data cover the western North Pacific to $170^{\circ} \mathrm{W}$ and from an equator to $60^{\circ} \mathrm{N}$, and are arranged for an area of $2^{\circ} \times 5^{\circ}$ (lat. $\times$ lon.). The marine meteorological

Fig. 6. Seasonal variations of relationship between the standard error and the number of the data obtained theoretically by Eq. (1). (a) East-west and (b) northsouth wind stresses $\left(\mathrm{dyn} \cdot \mathrm{cm}^{-2}\right)$, (c) sensible and (d) latent heat fluxes $\left(\mathrm{W} \cdot \mathrm{m}^{-2}\right)$. 


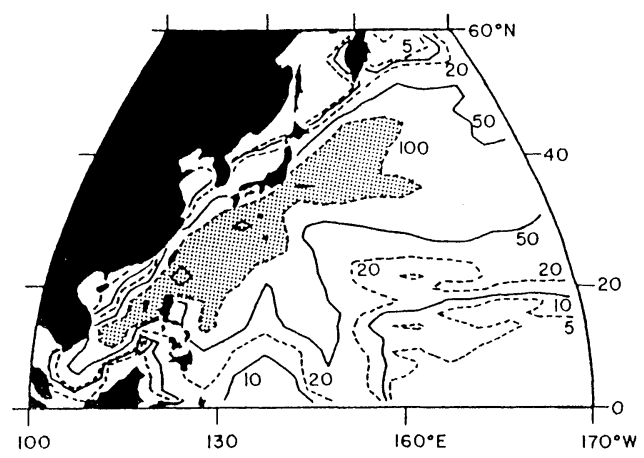

Fig. 7. Annual mean distribution of the number of the data per one month for the area of $2^{\circ} \times 5^{\circ}$ (lat. $x$ lon.) averaged during 25 years from 1961 to 1985 . These were obtained from the data compiled by the Japan Meteorological Agency. The shaded zones denote the regions having the data more than 100 in number and closed contours in the shaded zones correspond to 200 data.

elements examined here are wind speed, wind direction, air and dew point temperatures, SST, cloud amount, and air-sea temperature difference. The numbers of the data for each element which were slightly different from element to element were summed and averaged.
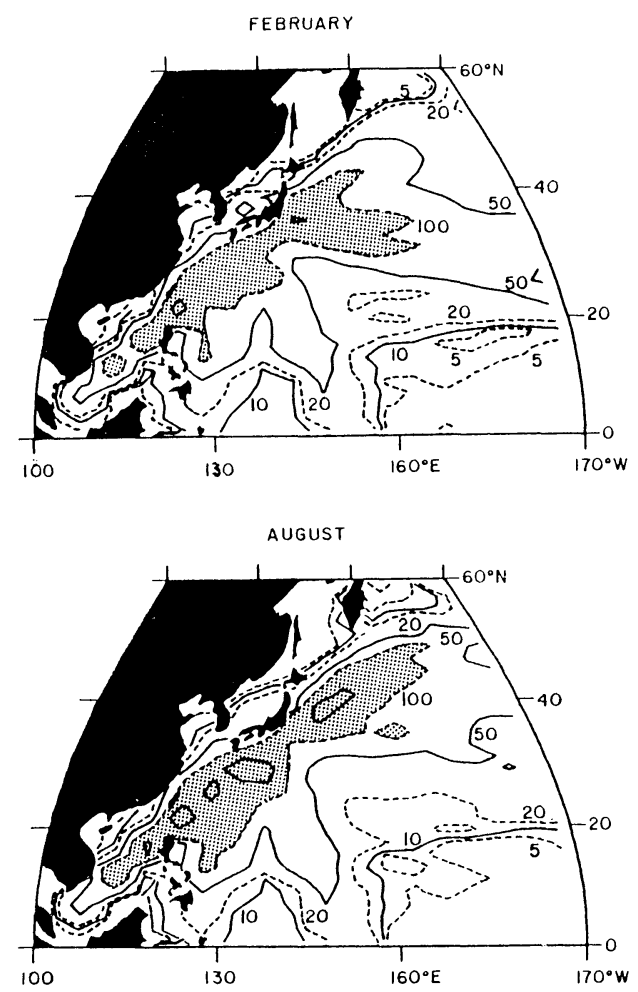

Figure 7 shows annual mean distribution of the number of the data per one month averaged from 1961 to 1985 , i.e., 25 years. Relatively dense areas of the data more than 100 in number lie on the ship courses from Japan towards the Strait of Malacca and to the North American Continent. In the latitudinal zone from 30 to $50^{\circ} \mathrm{N}$, and along the meridional zone from 150 to $155^{\circ} \mathrm{E}$ from Japan to Oceanian countries, the data exist more than 50 excluding an equatorial region. On the other hand, there are few data in the Okhotsk Sea, northern part of the Japan Sea, and an equatorial region east from $160^{\circ} \mathrm{E}$ and south from $20^{\circ} \mathrm{N}$.

Figure 8 shows the data distributions for February, May, August and November. It is seen that there is no remarkable change in the data distribution except for the ship course from Japan to the North American Continent. Though the course usually lies on the great circle from Japan, since the northern sea is stormy in winter, many ships take the course towards just east from Japan.
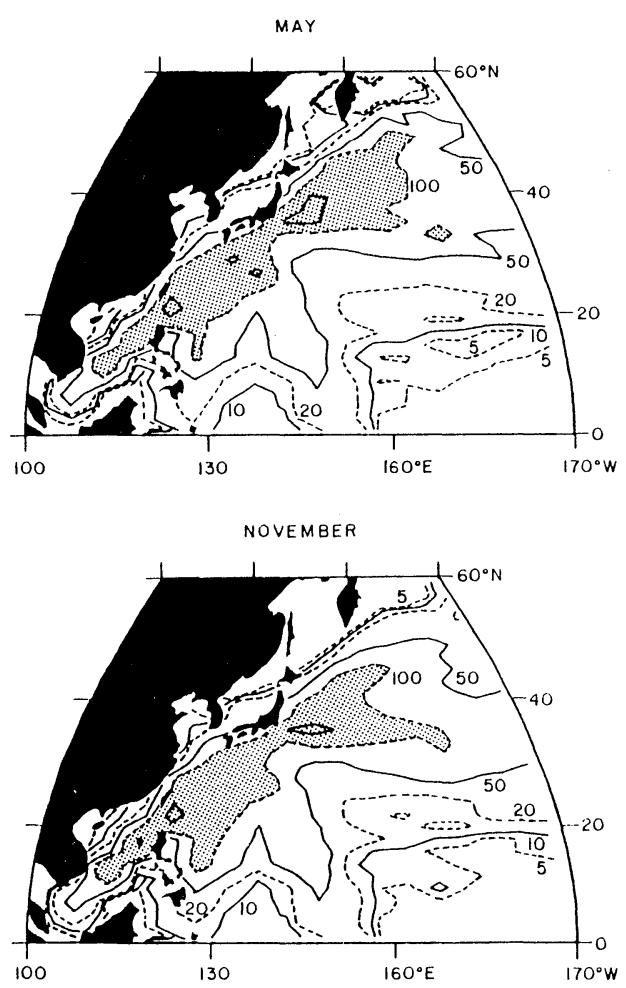

Fig. 8. As in Fig. 7, but for February, May, August and November. 


\section{Expected accuracy of heat and momentum fluxes in the sea south of Japan}

From the data distribution shown in Figs. 7 and 8, compared to Fig. 6, accuracies of fluxes at OWS $-\mathrm{T}$ are expected as follows: since the number of the data exceeds 100 for each month, accuracies expected for momentum fluxes are 0.15 and $0.1 \mathrm{dyn} \cdot \mathrm{cm}^{-2}$ in winter and summer, respectively, those for sensible heat fluxes 5 and $1 \mathrm{~W} \cdot \mathrm{m}^{-2}$ and those for latent heat fluxes 15 and $5 \mathrm{~W} \cdot \mathrm{m}^{-2}$.

Strictly speaking, these accuracies are appropriate for the quite vicinity of OWS-T. On the extent for above results to hold, examination is needed. Iwasaka et al. (1987b) who made the cluster analysis of monthly $5^{\circ} \times 5^{\circ}$ (lat. $\times$ lon.) SST anomalies in the North Pacific, showed that the sea area from 20 to $35^{\circ} \mathrm{N}$ and from 130 to $170^{\circ} \mathrm{E}$ has simialr SST variability and is partitioned as one cluster. On the other hand, Kutsuwada (1987) who analyzed monthly $2^{\circ} \times 5^{\circ}$ (lat. $x$ lon.) wind stress in the weatern North Pacific showed the result of one-point correlation analysis with reference area of $30-32^{\circ} \mathrm{N}, 135-140^{\circ} \mathrm{E}$, for two frequency bands, i.e., longer than 1.6 years and around 3.6 years. The high coherence region with correlation coefficient larger than 0.7 appeared as the zonal band along $30^{\circ} \mathrm{N}$ line from 125 to $150^{\circ} \mathrm{E}$.

Though the above results are indirect evidences, they suggest that marine meteorological elements have similar variability for scale of order of $10^{3} \mathrm{~km}$ or so. Therefore, roughly speaking, for the sea area from 25 to $35^{\circ} \mathrm{N}$ and from 130 to $145^{\circ} \mathrm{E}$, we may expect the accuracies described above.

\section{Discussion}

In the present paper, we examined the standard error of monthly mean air-sea heat and momentum fluxes depending on the number of the data, and based on the actual data distribution, we presented the expected accuracies in the sea south of Japan.

\section{Relationship between averaging time and spatial scales}

This problem is also difficult to answer, because we do not know the magnitude and dis- tribution of the spatial correlation coefficients of the marine meteorological elements exactly. In the present study, we have assumed a priori that the averaging area of $2^{\circ} \times 5^{\circ}$ (lat. $\times$ lon.) is appropriate spatial scale for the time scale of a month or so. This may be justified for the mid latitude to some extent, because the spatial scale of atmospheric disturbances is order of $10^{3} \mathrm{~km}$ and since the internal radius of deformation in the interior region of the subtropical gyre is about $40 \mathrm{~km}$, dominant spatial scale of several times of the radius may be expected for parameter in the oceanic side, i.e., SST.

\section{Estimation of accuracy for sea areas with no} continuous and/or dense data

Iwasaka et al. (1987a) who treated a large number of data for analyses of monthly mean SST variation in the North Pacific regarded the standard deviations calculated from the total data observed in each calendar month irrespective of years as that of the population, and estimated the expected accuracies by Eq. (1). The standard deviations obtained like this is not same as that of the population because of the randomly sampled data in strict sense. However, we may expect that the standard deviation approaches the real value as the number of the data increases. Therefore, the plausible way of estimation of the expected accuracies is considered as that mentioned above.

For the sea area and/or month with few data, it is dangerous for the data to be regarded as randomly sampled ones, because only one ship might make reports along her course. Therefore, since those data may give a large bias in flux estimation, we must pay special attention in data handling.

Other error sources in flux estimation by bulk method

In flux estimation by bulk method, we have another serious problems. Weare and Strub (1981) pointed out the error sources as follows: (1) the bulk formulae themselves, (2) number of marine reports, (3) quality of data, (4) temporal and spatial biassed sampling, e.g., uneven sampling throughout a month, and (5) random errors, e.g., miswriting. They considered item (4) for the Pacific equatorial region. The problem considered here just corresponds to their item (2). 
For item (1), Blanc $(1985,1987)$ showed the differences of the estimated fluxes due to the various bulk transfer coefficients (Note that the problem considered here does not largely depend on the kind of the bulk transfer coefficients used). The author believe that researchers who try to estimate air-sea fluxes had better estimate accuracies for them based on the data used as well, in order to improve reliability of their results.

\section{Acknowledgements}

The author would like to express his sincere thanks to Prof. Y. Toba and other members of Physical Oceanography Laboratory, Tohoku University for their useful comments, and especially to Mr. T. Watanabe for preparing the original data of Figs. 7 and 8. The author is also grateful to anonymous referee for his useful comments. This study was made as part of OMLET (chairman: Prof. Y. Toba), one of the Japanese WCRP activities, which was financially supported by Ministry of Education, Science and Culture, Japan.

\section{References}

Blanc, T.B., 1985: Variation of bulk derived surface flux, stability, and roughness results due to the use of different transfer coefficient schemes. J. Phys. Oceanogr., 15, 650-669.

- 1987: Accuracy of bulk-method-determined flux, stability, and sea surface roughness. J. Geophys. Res., 92, 3867-3876.

Hanawa, K. and Y. Toba, 1987: Critical examination of estimation methods of long-term mean air-sea heat and momentum transfers. Ocean-Air Int., 1, 77-93.

Hays, W.L., 1981: Statistics (3rd ed.). Holt-Saunders International Editors, pp. 723.

Iwasaka, N., K. Hanawa and Y. Toba, 1987a: Analysis of SST anomalies in the North Pacific and their relation to $500 \mathrm{mb}$ height anomalies over the northern hemisphere during 1969-1979. J. Meteor. Soc. Japan, 65, 103-114. and $1987 \mathrm{~b}$ : Partition of the North Pacific Ocean based on similarity in the SST anomaly variation. Submitted to J. Meteor.
Soc. Japan.

Kondo, J., 1975: Air-sea bulk transfer coefficients in diabatic condition. Bound-Layer Meteor., 9, 91112.

Kurasawa, Y., K. Hanawa and Y. Toba, 1983: Heat balance of the surface layer of the sea at Ocean Weather Station T. J. Oceanogr. Soc. Japan, 39, $170-192$.

Kutsuwada, K., 1987: Interannual variability of wind stress over the western North Pacific: Spatial characteristics. To be appeared in Mon. Wea. Rev.

Liu, W.T., 1987: 1982-1983 El Nino Atlas - Nimbus-7 microwave radiometer data -. Tech. Rep. J.P.L. Pub. 87-5, pp. 68.

Weare, B.C. and P.T. Strub, 1981: The significance of sampling biases on calculated monthly mean oceanic surface heat fluxes. Tellus, 33, 211-224.

\section{Appendix}

Computer simulation for randomly sampled and small-in-number data

The computer simulation was made for six kinds of the number of data: $5,10,20,30,50$ and 100 in number for a month. The procedures are as follows: first, the homogeneous random numerals ranging from 1 to $8 \times$ (days of the month to be simulated) was generated in the minicomputer (OKITAC System 50/10) by using the software $R A N D U$ provided by the computer maker. Then the corresponding observational data were chosen for flux estimation: for example, when the generated numeral is 81 , the data obtained at 0 o'clock on 11 th day of the month to be simulated were chosen. The same step was repeated as many as the predetermined number of the data. Then, flux was calculated from the simultaneous data set and monthly mean value was estimated (sampling method). The difference between each simulated monthly mean value and the real mean value shown in Fig. 2 was calculated. These trials were repeated 100 times for each case. Lastly, the standard deviation of the differences was obtained. This standard deviation was plotted in Fig. 5 with black and open circles. 


\title{
日本南方海域における大気海洋間の 熱と運動量フラックスの精度
}

\author{
花輪公雄 \\ (東北大学理学部地球物理学教室)
}

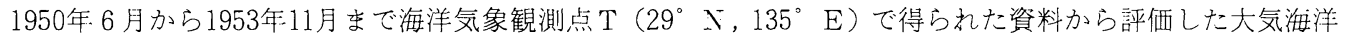
間の顕熱・潜熱，および，運動量フラックスに対する統計学的考察から，月平均值の譢差と資料数との関係を 検討した。資料数と，季節変化しているフラックスの標準偏差に依存する䛊差を，統計学の理論式から求めた。 それらは，母集団の標準偏差を資料数の平方根で割った值として与えられる。ランダムサンプリングした少数 の資料に対する計算機シミュレイションの結果は, 正規分布から外れている母集㖊に対しても, 上記の評価を 支持していた。気象庁が1961〜1985年の間にコンパイルした，西部北太平洋の海上気象資料数を調べたとこ ろ，日本南方海域では緯度経度 $2^{\circ}$ x 5 ○の海域でひと月に100個以上存在することがわかった。したがって， この海域では運動量フラックスは冬季・夏季に，それぞれ $0.15,0.1 \mathrm{dyn} \cdot \mathrm{cm}^{-2}$, 顕熱は $5,1 \mathrm{~W} \cdot \mathrm{m}^{-2}$, 潜熱は $15,5 \mathrm{~W} \cdot \mathrm{m}^{-2}$ 程度の精度で評価出来ることがわかった。
\end{abstract}

